\section{Commentary: Coronary artery bypass grafting before or after stenting; same game, different half?}

\author{
Richard Lee, MD, JD, MBA, and Neal Weintraub, MD
}

We read the article of Cheng and colleagues, ${ }^{1}$ "Effect of Previous Coronary Stenting on Subsequent Coronary Artery Bypass Graft Outcome," with great interest after viewing the central message: can early mortality be decreased by a strategy of initial bypass surgery in lieu of stenting? When we reviewed the article together, however, our hope and enthusiasm waned. Even though we applaud the authors for the rigorous propensitymatched analysis of a large population in a single country, several limitations prohibit us from embracing its message.

The most critical flaw is presuming the propensity match corrects for selection bias of the disease. For example, the patients in these 2 groups may be at different stages or trajectories of their disease. Those patients treated initially with stenting who then proceed to undergo bypass surgery likely exhibit a more advanced state of coronary artery disease as compared with those who undergo bypass surgery as the initial revascularization approach. The only way to address this issue would be to perform a randomized trial of stenting versus bypass surgery in patients who were not previously revascularized, with subsequent re-randomization in the patients who did not respond to stenting. This will unlikely ever occur. If reading this study were like watching a football game, it would be akin to viewing the

\footnotetext{
From the Division of Cardiothoracic Surgery, Department of Surgery, Medical College of Georgia, Augusta University, Augusta, Ga.

Disclosures: The authors reported no conflicts of interest.

The Journal policy requires editors and reviewers to disclose conflicts of interest and to decline handling or reviewing manuscripts for which they may have a conflict of interest. The editors and reviewers of this article have no conflicts of interest.

Received for publication Sept 29, 2020; revisions received Sept 29, 2020; accepted for publication Sept 30, 2020; available ahead of print Oct 7, 2020.

Address for reprints: Richard Lee, MD, JD, MBA, Department of Surgery, Medical College of Georgia, 1120 15th St, BA 4300, Augusta, GA 30912 (E-mail: richardleemdmba@gmail.com or RICKLEE@augusta.edu).

J Thorac Cardiovasc Surg 2022;164:940-1

$0022-5223 / \$ 36.00$

Copyright (C) 2020 by The American Association for Thoracic Surgery

https://doi.org/10.1016/j.jtcvs.2020.09.124
}

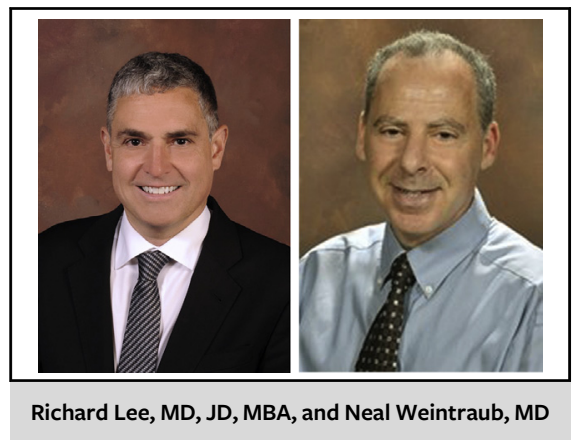

CENTRAL MESSAGE

Patients who undergo coronary

artery stenting before bypass are

likely at a later point in the pro-

gression of their disease as

compared with those who un-

dergo bypass as initial therapy.

second half only, leaving fans to guess what happened in the first half. Such an exercise has value, but it does not provide the substance required for the conclusion. Another analogy would be comparing outcomes in patients with primary versus recurrent cancer.

A second issue with the message is that the survival curves appear to cross at year 5 , with previous stenting mortality being lower. It is unclear if the follow-up influences outcome, although this seems plausible, as followup early after coronary bypass may be more intense initially and then relaxed over time. It is clear that previously stented patients receive more subsequent stents, which may impact survival long term. We are not given the cause of death at any time point, so any hypotheses are mere speculation.

Finally, the population and outcomes make the data too difficult to interpret. Thirty-day mortality is between $5 \%$ and $7.2 \%$ in the 2 groups in an era that large series (and the Society of Thoracic Surgeons Database) would expect mortalities between $1 \%$ and $2.8 \%$ for isolated coronary artery bypass grafting-even in the highest risk quintilewhich addresses the same underlying isolated coronary artery disease. ${ }^{2,3}$ The disparity can be partially, but not completely, explained by the inclusion of concomitant valve surgery in about $6 \%$ of the patients. In addition, data on left ventricular function are not included in this study. There was a trend toward increased use of mechanical support (intra-aortic balloon pump and extracorporeal 
membrane oxygenation) in patients who underwent stenting before bypass surgery, which could have impacted early mortality in this group.

Overall, this paper does raise an important question that merits further investigation. This paper is important in helping focus future efforts at determining the impact of stenting before coronary bypass grafting over the entire duration of the disease process.

\section{References}

1. Cheng Y-T, Chen D-Y, Chien-Chia Wu V, Chou A-H, Chang S-H, Chu PH, et al Effect of previous coronary stenting on subsequent coronary artery bypass grafting outcomes. J Thorac Cardiovasc Surg. 2022;164:928-39.e5.

2. Biancari F, Dalen M, Ruggieri VG, Demal T, Gatti G, Onorati F, et al. Prognostic impact of multiple prior percutaneous coronary interventions in patients undergoing coronary artery bypass grafting. J Am Heart Assoc. 2018;7:e010089.

3. Englum BR, Saha-Chaudhuri P, Shahian DM, O'Brien SM, Brennan JM Edwards FH, et al. The impact of high-risk cases on hospitals' risk-adjusted coronary artery bypass grafting mortality rankings. Ann Thorac Surg. 2015;99:856-62.
See Article page 928.

\section{Commentary: What is the impact of previous coronary stenting for coronary artery bypass graft outcomes?}

\author{
Louis-Mathieu Stevens, MD, $\mathrm{PhD}$, and
} Nicolas Noiseux, MD, MSc

Cheng and colleagues ${ }^{1}$ have studied the effect of previous coronary stenting on subsequent multivessel coronary artery bypass grafting $(\mathrm{CABG})$ outcomes using the Taiwan's National Health Insurance administrative database between 2000 and 2013. From a pool of 32,335 patients of whom 3028 had previous coronary stenting, the authors were able to obtain 2977 propensity score-matched pairs. It is unclear why they included "discharge medication" in their propensity score, which selected patients without previous stenting more likely to require clopidogrel, statin, or angiotensin-converting enzyme inhibitors/angiotensin receptor blockers treatment, like patients with recent myocardial infarction. Their cohort included few patients with concomitant valve surgery $(5.6 \%)$ but excluded patients with reoperation, aortic surgery, or coronary stenting during the same hospital admission. The authors showed that

\footnotetext{
From the Division of Cardiac Surgery, Centre hospitalier universitaire de l'Université de Montréal, Montreal, Quebec, Canada.

Disclosures: The authors reported no conflicts of interest.

The Journal policy requires editors and reviewers to disclose conflicts of interest and to decline handling or reviewing manuscripts for which they may have a conflict of interest. The editors and reviewers of this article have no conflicts of interest.

Received for publication Sept 21, 2020; revisions received Sept 21, 2020; accepted for publication Sept 23, 2020; available ahead of print Sept 28, 2020.

Address for reprints: Louis-Mathieu Stevens, MD, PhD, Division of Cardiac Surgery, Centre hospitalier de l'Université de Montréal, 900 Saint-Denis St, Montreal, Quebec, Canada, H2X 0A9 (E-mail: 1m.stevens@umontreal.ca).

J Thorac Cardiovasc Surg 2022;164:941-2

$0022-5223 / \$ 36.00$

Copyright (C) 2020 by The American Association for Thoracic Surgery

https://doi.org/10.1016/j.jtcvs.2020.09.089
}

Check for updates

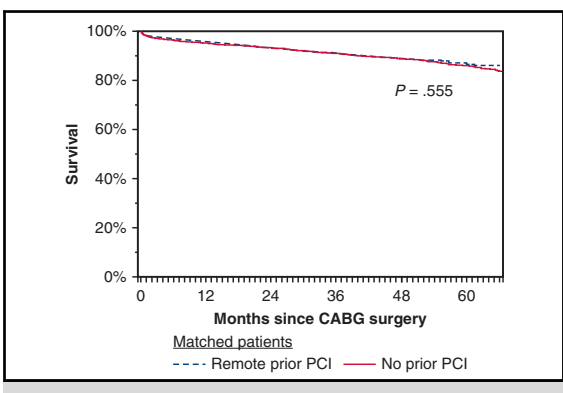

Survival after CABG for matched patients with remote prior $\mathrm{PCl}$ ( $>14$ days) versus no $\mathrm{PCI}$. Adapted with permission.

\section{CENTRAL MESSAGE \\ Timing between coronary stent- ing and coronary bypass grafting influences short-term outcomes but not survival. CABG patients with prior stenting are more likely to require repeat revascularization.}

patients undergoing $\mathrm{CABG}$ with previous coronary stenting experienced more 30-day mortality, but previous coronary stenting did not affect late survival at a median follow-up of 3.1 years. It is unfortunate that their health insurance database was not maintained after 2013 and no other database could have been used to provide longer follow-up. Moreover, it would have been interesting to assess whether the timing between coronary stenting and CABG influence postoperative outcomes.

In 2010 , we used a similar methodology with a $1: 3$ propensity score matching ratio to assess the impact of previous coronary stenting using the mandatory Massachusetts Adult Cardiac Surgery clinical database. ${ }^{2}$ To improve 